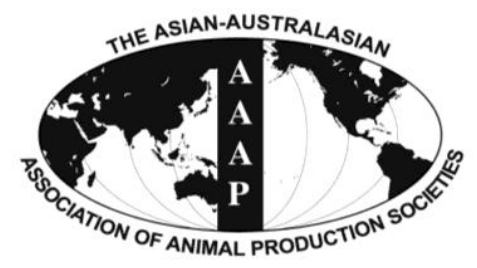

Asian-Aust. J. Anim. Sci.

Vol. 25, No. 2 : 248 - 255

February 2012

www.ajas.info

http://dx.doi.org/10.5713/ajas.2011.11211

\title{
Effects of Boron Supplementation to Diets Deficient in Calcium and Phosphorus on Performance with Some Serum, Bone and Fecal Characteristics of Broiler Chickens
}

\author{
Mehmet Bozkurt*, Kamil Küçükyılmaz, Abdullah Uğur Çatlı, Mustafa Çınar, \\ Metin Çabuk ${ }^{1}$ and Erol Bintaş \\ Erbeyli Poultry Research Institute, İncirliova, Aydın, Turkey
}

\begin{abstract}
Three levels of boron $(0,30,60 \mathrm{ppm})$ were supplemented in practical corn-soybean based starter and grower diets, containing either adequate or inadequate $\mathrm{Ca}$ or $\mathrm{P}$. A total of 1,800, 1-day-old sexed broiler chicks were assigned to six dietary treatments and fed with the experimental diets for 42 days. Boron improved the overall feed conversion ratio, but increased body weight only at 21 days of age $(\mathrm{p}<0.01)$. Boron decreased feed intake in the case of feeding on a diet deficient in $\mathrm{Ca}$ and $\mathrm{P}$, and tended to increase feed intake when birds received a diet adequate in $\mathrm{Ca}$ and $\mathrm{P}$, signifying significant boron by Ca-P interaction $(\mathrm{p}<0.01)$. Mortality was not influenced by boron $(\mathrm{p}>0.05)$. Dietary $\mathrm{Ca}$ and $\mathrm{P}$ deprivation reduced body weight and feed consumption significantly, but did not influence the feed conversion ratio and mortality ( $p>0.05)$. Serum Ca level, ALP and ALT activities were not influenced either by dietary $\mathrm{Ca}$ and $\mathrm{P}$ deficiency or boron supplementation. Serum $\mathrm{P}$ content increased with respect to boron at $30 \mathrm{ppm}$. Bone breakage strength was not affected by dietary variables. Tibia ash, $\mathrm{Ca}$ and $\mathrm{P}$ were increased in response to the supplementation diet with $30 \mathrm{ppm}$ boron, whereas $60 \mathrm{ppm}$ showed no effect in most cases. Accordingly, the dietary boron supplementation of $30 \mathrm{ppm}$ significantly decreased fecal $\mathrm{Ca}$ and $\mathrm{P}$ excretion, while there was a numerical decline in the $60 \mathrm{ppm}$ boron as compared to the 0 ppm boron group. Data presented herein indicated that boron, either at the $30 \mathrm{ppm}$ or $60 \mathrm{ppm}$ supplementation level, was effective in conversion of feed to body weight, whereas only boron at $30 \mathrm{ppm}$ contributed to the mineralization of bone thereby augmenting more $\mathrm{Ca}$ and $\mathrm{P}$ while excreting less through faeces. (Key Words : Boron, Broiler, Growth, Metabolic Profile, Bone Structure, Fecal Excretion)
\end{abstract}

\section{INTRODUCTION}

Since boron has not been consistently accepted as an essential element for higher animals and plants, its importance in poultry nutrition has been recognized only since the late 1980s. Initial work indicated that boron may improve the growth rate, nutritional efficiency, liveability, calcium, and phosphorus retention in broilers while reducing symptoms of vitamin D deficiency (Hunt, 1989; Rossi et al., 1993). Moreover, subsequent studies (Kurtoğlu et al., 2001, 2005; Fassani et al., 2004) also confirmed those observations. Several authors suggested that a dietary boron deficiency affects normal development and cartilage of bone, bone ash and bone breaking load, and plasma $\mathrm{Ca}, \mathrm{P}$,

\footnotetext{
* Corresponding Author : Mehmet Bozkurt. Tel: +90-256-5811123, Fax: +90-256-5811123, E-mail: mehmetbozkurt9@hotmail.com

${ }^{1}$ Department of Poultry Science, Vocational School of Celal Bayar University, Akhisar, Manisa, Turkey.

Received July 7, 2011; Accepted October 28, 2011
}

Mg levels with ALP activity (Nielsen, 1992; Nielsen and Shuler, 1992; Kurtoğlu et al., 2001).

However, the correlations between boron and $\mathrm{Ca}$, and boron and $\mathrm{P}$, dealing with growth performance and bone mineralization have not been firmly established. Hunt (1989) reported that boron increased plasma $\mathrm{Ca}$ and $\mathrm{Mg}$ concentrations in broiler chicks when the birds were fed with diets deficient in magnesium. Eliot and Edwards (1992) could not determine an interaction between supplemental doses of boron and $\mathrm{Ca}$ through six experiments with purified diets. Limited evidence suggested that boron supplementation affected the metabolism of $\mathrm{Ca}$, $\mathrm{P}$ and $\mathrm{Mg}$ in rats (Hegsted et al., 1981; Nielsen and Shuler, 1992), humans (Nielsen et al., 1987) and pigs (Armstrong and Spears, 2001). Therefore, there is a need to define the mechanism through which boron could compensate for the dietary $\mathrm{Ca}$ and $\mathrm{P}$ deficiency in more recent broiler strains more clearly, because it lacks a defined biochemical function. 
Results obtained from the studies with boron over the past three decades show substantial inconsistencies, since supplemental boron has promoted broiler performance in several trials (Rossi et al., 1993; Kurtoğlu et al., 2001; Fassani et al., 2004) while either inhibiting or not influencing growth in some cases (Eliot and Edwards, 1992). Several earlier works also suggested that dietary boron administration in broilers (Eliot and Edwards, 1992; Kurtoğlu et al., 2005) growing pullets (Wilson and Ruszler, 1997), laying hens (Wilson, 1998), and broiler breeders (Qin and Klandorf, 1991) improved some of the mechanical and mineral properties of bone, including resistance to breaking strength, shear force, ash content, and mineral concentration.

These findings prompted an investigation designed to characterize the interactions between dietary $\mathrm{Ca}-\mathrm{P}$ and boron by providing two levels of boron previously found beneficial to broilers. Therefore, boron at $30 \mathrm{ppm}$ or $60 \mathrm{ppm}$ was supplemented to corn-soybean-based practical diets, either adequate or deficient in both $\mathrm{Ca}$ and $\mathrm{P}$.

\section{MATERIALS AND METHODS}

\section{Birds and housing}

A feeding experiment was done on 1,800 feather-sexed 1-day-old broiler chicks of a commercial strain (Ross-308). The experiment was conducted with a corn-soybean diet, with a $2 \times 3$ factorial arrangement of treatments with calcium and phosphorus at standard and lower levels, and supplemental boron at the levels of 0,30 and $60 \mathrm{mg} / \mathrm{kg}$. The birds were randomly assigned to six dietary treatments, replicated six times as presented in Table 1 . Fifty birds per pen, 25 male and 25 female chicks, were assigned at random to each replicate and placed in floor pens. The birds were kept in 36 wire pens $(2.4 \times 1.6 \mathrm{~m})$ on wood shavings as litter material. Bird density was 13 chicks per square meter. Each pen was equipped with two hanging feeders and one bell-type drinker. The birds were given ad libitum access to feed and water. Birds were reared in an environmentally controlled grower house with an automatic heating and ventilation system. The lighting cycle was $23 \mathrm{~h} / \mathrm{d}$ maintained. The ambient temperature in the experimental

Table 1. Experimental design

\begin{tabular}{|c|c|c|c|c|c|}
\hline \multirow[b]{2}{*}{ Groups } & \multirow{2}{*}{$\begin{array}{l}\text { Boron } \\
\text { (ppm) }\end{array}$} & \multicolumn{2}{|c|}{ Diet Ca level (\%) } & \multicolumn{2}{|c|}{ Diet available $\mathrm{P}$ level (\%) } \\
\hline & & $\begin{array}{c}\text { Starter } \\
\text { diet }\end{array}$ & $\begin{array}{c}\text { Grower } \\
\text { diet }\end{array}$ & $\begin{array}{c}\text { Starter } \\
\text { diet }\end{array}$ & $\begin{array}{c}\text { Grower } \\
\text { diet }\end{array}$ \\
\hline 1 & 0 & 0.95 & 0.85 & 0.46 & 0.38 \\
\hline 2 & 30 & 0.95 & 0.85 & 0.46 & 0.38 \\
\hline 3 & 60 & 0.95 & 0.85 & 0.46 & 0.38 \\
\hline 4 & 0 & 0.85 & 0.75 & 0.40 & 0.32 \\
\hline 5 & 30 & 0.85 & 0.75 & 0.40 & 0.32 \\
\hline 6 & 60 & 0.85 & 0.75 & 0.40 & 0.32 \\
\hline
\end{tabular}

house was thermostatically controlled by a heating system and wall fans. This temperature was set at $32^{\circ} \mathrm{C}$ on the first three days day of the experiment and gradually decreased $1^{\circ} \mathrm{C}$ every third day until 21 days of age and maintained at $22^{\circ} \mathrm{C}$ thereafter. On day 12 and 18 chicks were vaccinated against infectious bursal disease and Newcastle disease, respectively, via drinking water.

\section{Experimental diets}

Corn-soybean based commercial starter and grower diets, either adequate or deficient in $\mathrm{Ca}$ and $\mathrm{P}$, were given to broiler chickens during a 42-day experimental period. $\mathrm{Ca}$ and $\mathrm{P}$ levels in the standard diet were adjusted to the NRC's recommendations (1994). Ca and P levels were reduced by degrees ranging from 12 to $18 \%$ to establish experimental deficiency; this diet was described as Ca-P deficient throughout the paper. Boron was supplemented in both types of diets at the level of 0,30 and $60 \mathrm{mg} / \mathrm{kg}$, respectively. Boric acid $\left(\mathrm{H}_{3} \mathrm{BO}_{3}\right)$ was used as the boron source. It was provided by a government institute (BOREN, Ankara, Turkey) dedicated to boron research. The boric acid contained $18 \%$ boron, and $167 \mathrm{~g}$ and $334 \mathrm{~g}$ boric acid per ton of basal diet were included to supply boron at $30 \mathrm{mg} / \mathrm{kg}$ and $60 \mathrm{mg} / \mathrm{kg}$ levels, respectively. In order to ensure homogenous distribution, those boric acid preparations in powdered form were added to the feed mixture after premixing. For this purpose, calculated amounts of boric acid preparations were added into $833 \mathrm{~g}$ and $664 \mathrm{~g}$ fine wheat bran, $1 \mathrm{~kg}$ of each, mixed in a laboratory type mixer for $30 \mathrm{~s}$, and then supplemented into one ton of the basal diet. The ingredient and chemical composition of the basal diets are presented in Table 2. Basal starter diets either adequate or deficient in Ca-P included 2.36, 2.14 ppm boron respectively. Those were measured as 2.04 and $2.23 \mathrm{ppm}$ in grower diets. Analyzed values of boron in experimental starter diets added with 30 and 60 ppm boron were 33.28 and $59.74 \mathrm{ppm}$ in standard $\mathrm{Ca}-\mathrm{P}$ diets while those were 29.09 and 65.44 ppm in Ca-P deficient diets. Corresponding boron values in grower diets were 28.93 and 65.31 in standard Ca-P diets, and $35.47 \mathrm{ppm}$ and $59.03 \mathrm{ppm}$ in Ca-P deficient diets. Experimental diets were in mash form and met or exceeded NRC (1994) nutrient recommendations for broilers. Diets were isoenergetic and isonitrogeneous. Birds were fed a starter diet from days 1 to 21 and a grower diet from days 22 to 42 .

The standard techniques of the proximate analysis were used to determine the nutrient concentrations in the diets (Naumann and Bassler, 1993). The experimental diets were analyzed for starch, sugar, total calcium and phosphorus according to chemical analyses methods of feedstuff by Association of German Agricultural Analysis and Research Institutes (VDLUFA) (Naumann and Bassler, 1993). The metabolisable energy content of the diet was calculated 
Table 2. Ingredients and chemical composition of the starter and grower diets

\begin{tabular}{|c|c|c|c|c|}
\hline \multirow{2}{*}{ Ingredients $(\mathrm{g} / \mathrm{kg})$} & \multicolumn{2}{|c|}{ Broiler starter diet } & \multicolumn{2}{|c|}{ Broiler grower diet } \\
\hline & Std. Ca-P & Deficient Ca-P & Std. Ca-P & Deficient $\mathrm{Ca}-\mathrm{P}$ \\
\hline Corn & 55.18 & 56.06 & 61.01 & 61.87 \\
\hline Soybean meal (\% 48) & 37.37 & 37.22 & 30.59 & 30.44 \\
\hline Vegetable oil & 3.28 & 3.03 & 4.72 & 4.44 \\
\hline Limestone & 1.30 & 1.23 & 1.20 & 1.11 \\
\hline Dicalcium phosphate & 1.64 & 1.31 & 1.50 & 1.16 \\
\hline Sodium chloride & 0.25 & 0.25 & 0.25 & 0.25 \\
\hline Vitamin premix $^{1}$ & 0.25 & 0.25 & 0.25 & 0.25 \\
\hline Mineral premix ${ }^{2}$ & 0.10 & 0.10 & 0.10 & 0.10 \\
\hline $\mathrm{L}$ - lysine $\mathrm{HCl}$ & 0.22 & 0.23 & 0.11 & 0.11 \\
\hline DL-methionine & 0.21 & 0.22 & 0.17 & 0.17 \\
\hline Anticoccidial & 0.10 & 0.10 & 0.10 & 0.10 \\
\hline Wheat bran & 0.10 & 0.10 & 0.10 & 0.10 \\
\hline \multicolumn{5}{|l|}{ Chemical composition (\%) } \\
\hline Dry matter & 90.22 & 90.35 & 90.30 & 90.09 \\
\hline Crude protein & 21.82 & 22.13 & 20.05 & 20.02 \\
\hline Ether extract & 5.63 & 5.40 & 7.28 & 7.04 \\
\hline Crude fibre & 3.62 & 3.63 & 3.52 & 3.53 \\
\hline Crude ash & 6.25 & 5.85 & 5.69 & 5.27 \\
\hline Calcium & 0.95 & 0.85 & 0.85 & 0.74 \\
\hline Total phosphorus & 0.66 & 0.60 & 0.62 & 0.56 \\
\hline Boron (ppm) & 2.36 & 2.14 & 2.04 & 2.23 \\
\hline AME (kcal/kg) & 3,023 & 3,051 & 3,171 & 3,185 \\
\hline \multicolumn{5}{|c|}{ Calculated composition (\%) } \\
\hline Available phosphorus & 0.46 & 0.38 & 0.40 & 0.32 \\
\hline Lysine & 1.26 & 1.26 & 1.16 & 1.16 \\
\hline Methionine+cystine & 0.91 & 0.92 & 0.80 & 0.80 \\
\hline
\end{tabular}

${ }^{1}$ Provides per kg of diet: vitamin A 12,000 IU; vitamin $\mathrm{D}_{3} 1,500 \mathrm{IU}$; vitamin E $75 \mathrm{mg}$; vitamin $\mathrm{K}_{3} 5 \mathrm{mg}$; vitamin $\mathrm{B}_{1} 3 \mathrm{mg}$; vitamin $\mathrm{B}_{2} 6 \mathrm{mg}$; vitamin $\mathrm{B}_{6} 5$ mg; vitamin $B_{12} 0.03 \mathrm{mg}$; nicotine amid $40 \mathrm{mg}$; calcium-D-pantothenate $10 \mathrm{mg}$; folic acid $0.75 \mathrm{mg}$; D-biotin $0.075 \mathrm{mg}$; choline chloride $375 \mathrm{mg}$.

${ }^{2}$ Provides per kg of diet: Mn 80 mg; Fe 40 mg; Zn 60 mg; Cu 5 mg; I 0.5 mg; Co, 0.2 mg; Se 0.15 mg.

from chemical composition (Anonymous, 1991). Basal starter and grower diets and also boron added experimental diets were analyzed for boron. Ground samples were dryashed (AOAC, 1990) and concentrations of boron were measured at a specific wavelength for this element (B, $249.677 \mathrm{~nm}$ ) by using an ICP (Perkin Elmer Optima 2100 DV). Calibration for the mineral assay was conducted with a series of mixtures containing graded concentrations of standard solutions (Merck, 170307 Boron ICP standard).

\section{Growth performance}

The growth performance of broilers was evaluated by recording body weight, body weight gain, feed intake, feed conversion ratio and mortality. The body weights of broilers in each pen were measured individually on day 21 and 42 . On the same days, the feed conversion ratio was calculated as the amount of feed consumed per unit of body weight gain, adjusting for weight at hatch and bird mortality. Mortality was recorded daily.

\section{Biochemical parameters}

Twelve birds were selected randomly from each treatment group (two birds per replicate pen) at 42 days of age. Blood samples were collected by cardiac puncture and placed into non-additive blood collection tubes in order to separate the serum. Sera were separated by centrifugation at $1,800 \times \mathrm{g}$ after $1 \mathrm{~h}$ of incubation at room temperature and stored at $-20^{\circ} \mathrm{C}$ until the analysis. Serum $\mathrm{Ca}$, inorganic $\mathrm{P}$ concentrations and alkaline phosphatase (ALP) activity were measured with a spectrophotometer (Hitachi, 911) using commercial kits (Roche, Basel, Sweden). Commercially available assay kits (Sigma, St. Louis, MO) 
were used to determine serum alanine aminotransaminase (ALT) activities.

\section{Bone breaking strength}

At the end of the experiment, two birds per experimental unit (twelve birds per treatment) were killed by cervical dislocation. After removing left tibias for determination of bone ash and mineral content, right tibias were excised from the fresh carcasses and all flesh was removed. The tibias were individually sealed in plastic bags to minimize moisture loss. The sample bags were placed into a plastic container and stored at $-20^{\circ} \mathrm{C}$ until analysis. The bones were thawed at room temperature for $6 \mathrm{~h}$ in an air-conditioned room before the measurement began. Tibia breaking strength (breaking force divided by unit bone surface area expressed as Newton per $\mathrm{cm}^{2}$ ) were measured using a related instrument (Shimadzu Ag-50 kng, Autograph) with $175 \mathrm{KN} / \mathrm{mm}$ load cell at a speed of 50 $\mathrm{mm} / \mathrm{min}$.

\section{Faeces collecting and analysis}

Following the 36-day growing period, twelve birds per treatment (one male and one female bird per replicate) were selected randomly and transferred to an offsite cage facility. Birds were placed in colony cages as groups, allowing the collection of faeces. Birds were maintained in their respective experimental treatments and had ad libitum access to feed and water. Broilers were allowed to adjust cage management for 3 days, followed by a 3-d total collection of faeces between days 39 and 42 . Fecal samples were collected for 3 consecutive days (minimum 500 $\mathrm{g} / \mathrm{d} /$ treatment), were homogenously mixed and stored at $-20^{\circ} \mathrm{C}$ until analysis. Fecal samples were analyzed for ash, $\mathrm{Ca}$ and $\mathrm{P}$ contents in order to determine the level of mineral excretion. For this purpose, samples of excrete were dryashed (AOAC, 1990) and concentrations of minerals were measured at specific wavelengths for each element $(\mathrm{Ca}$, 315.887; P, $214.914 \mathrm{~nm}$ ) by using an ICP (Perkin Elmer Optima 2100 DV). Calibrations for the mineral assays were conducted with a series of mixtures containing graded concentrations of standard solutions (Merck, 170373 Calcium ICP Standard and Merck, 170340 Phosphorus ICP Standard) of each element. Ash content was measured by dividing ash weight to initial faeces weight as describing percentage weight.

\section{Preparation of tibia for bone ash and bone mineral analysis}

Left tibias with some attached flesh were collected for measuring bone ash and bone mineral content. The tibias were excised and all flesh and proximal cartilages were removed. Bones were sealed individually in plastic bags and then stored at $-20^{\circ} \mathrm{C}$ until analysis. The bones were thawed at room temperature for $6 \mathrm{~h}$ in an air conditioned room before the analysis began. Each tibia was broken into small pieces, weighed and then ashed at $600^{\circ} \mathrm{C}$ for $12 \mathrm{~h}$. The percentage of tibia ash was calculated by dividing tibia ash weight by tibia weight and multiplying by 100 .

Bone samples were analyzed for ash, $\mathrm{Ca}$ and $\mathrm{P}$ contents to determine the level of mineral excretion. For this purpose, excreta samples were dry-ashed (AOAC, 1990) and concentrations of minerals were measured at specific wavelengths for each element (Ca, 315.887; P, $214.914 \mathrm{~nm}$ ) by using an ICP (Perkin Elmer Optima 2100 DV). Calibrations for the mineral assays were conducted with a series of mixtures containing graded concentrations of standard solutions of each element (Merck, 170373 Calcium ICP Standard and Merck, 170340 Phosphorus ICP Standard).

\section{Statistical analysis}

The experiment used a completely randomized design. The data was analyzed on a two-factorial ANOVA using the GLM procedure found in SAS software (SAS Institute, 1991). The main effects of Ca-P level, boron, and boron by Ca-P level interaction were tested. Significant differences between treatment means were separated using the Duncan's multiple range test with a $5 \%$ probability.

\section{RESULTS}

Table 3 presents body weight, feed intake, feed conversion ratio and mortality of birds at 21 days and 42 days of age. Boron supplementation into diet promoted body weight at 21 days of age, but not influenced at day 42 . However, reducing the dietary Ca-P level induced significant reduction $(\mathrm{p}<0.01)$ of body weight at both 21 and 42 days of age.

Significant boron by Ca-P interaction regarding feed intake was found between days 1 to 21 and 1 to $42(\mathrm{p}<0.01)$. This is because boron supplementation of Ca-P deficient diet decreased feed intake, whereas numerical increases were seen when birds fed on a standard diet. Reduced dietary Ca-P levels depressed feed intake from 1 to 21 days of age $(\mathrm{p}<0.01)$ and over the whole growing period (1 to 42 days) near to statistical significance $(\mathrm{p}=0.08)$. Boron at both inclusion levels improved the feed conversion ratio at a rate such that no added group exhibited similar efficiency $(\mathrm{p}<0.01)$ while deprivation of $\mathrm{Ca}$ and $\mathrm{P}$ did not deteriorate the efficiency of feed conversion. The mortality was very low compared to commercial field scores, and was not influenced by any of the dietary variables $(\mathrm{p}<0.05)$.

Serum Ca concentration, and ALP and ALT activities, were not influenced by deficiency in $\operatorname{diet} \mathrm{Ca}$ and $\mathrm{P}$ or 
Table 3. Performance parameters of broiler chickens fed on standard or Ca-P deficient diets supplemented with or without boron

\begin{tabular}{|c|c|c|c|c|c|c|c|c|c|}
\hline \multirow[b]{2}{*}{$\mathrm{Ca}-\mathrm{P}(\%)$} & \multirow[b]{2}{*}{$\begin{array}{l}\text { Boron } \\
\text { (ppm) }\end{array}$} & \multicolumn{4}{|c|}{$1-21 \mathrm{~d}$} & \multicolumn{4}{|c|}{$1-42 \mathrm{~d}$} \\
\hline & & $\begin{array}{c}\text { Body weight } \\
\text { (g) }\end{array}$ & $\begin{array}{c}\text { Feed intake } \\
(\mathrm{g})\end{array}$ & $\begin{array}{c}\text { FCR } \\
\text { (g feed/ } \\
\text { g gain) }\end{array}$ & $\begin{array}{c}\text { Mortality } \\
(\%)\end{array}$ & $\begin{array}{c}\text { Body weight } \\
(\mathrm{g})\end{array}$ & $\begin{array}{l}\text { Feed intake } \\
(\mathrm{g})\end{array}$ & $\begin{array}{c}\text { FCR } \\
\text { (g feed/ } \\
\text { g gain) }\end{array}$ & $\begin{array}{c}\text { Mortality } \\
(\%)\end{array}$ \\
\hline Standard & 0 & $714^{\mathrm{c}}$ & $1,081^{\mathrm{a}}$ & $1.612^{\mathrm{a}}$ & $0.66^{\mathrm{abc}}$ & 2,233 & $4,218^{\mathrm{bc}}$ & $1.926^{\mathrm{ab}}$ & 1.00 \\
\hline Standard & 30 & $736^{\mathrm{a}}$ & $1,080^{\mathrm{a}}$ & $1.559^{\mathrm{bc}}$ & $0.66^{\mathrm{abc}}$ & 2,287 & $4,254^{\mathrm{ab}}$ & $1.896^{\mathrm{bc}}$ & 1.00 \\
\hline Standard & 60 & $733^{\mathrm{ab}}$ & $1,092^{\mathrm{a}}$ & $1.584^{\mathrm{abc}}$ & $0.33^{\mathrm{bc}}$ & 2,269 & $4,265^{\mathrm{ab}}$ & $1.916^{\mathrm{bc}}$ & 0.66 \\
\hline Deficient & 0 & $712^{c}$ & $1,076^{\mathrm{a}}$ & $1.608^{\mathrm{ab}}$ & $2.00^{\mathrm{a}}$ & 2,240 & $4,310^{\mathrm{a}}$ & $1.961^{\mathrm{a}}$ & 2.33 \\
\hline Deficient & 30 & $722^{\mathrm{bc}}$ & $1,043^{\mathrm{b}}$ & $1.536^{\mathrm{c}}$ & $1.66^{\mathrm{ab}}$ & 2,222 & $4,105^{\mathrm{d}}$ & $1.884^{\mathrm{c}}$ & 1.66 \\
\hline Deficient & 60 & $710^{\mathrm{c}}$ & $1,033^{\mathrm{b}}$ & $1.549^{\mathrm{c}}$ & $0.00^{\mathrm{c}}$ & 2,231 & $4,146^{\mathrm{cd}}$ & $1.894^{\mathrm{c}}$ & 1.00 \\
\hline SEM & & 5.01 & 7.59 & 0.017 & 0.523 & 16.95 & 31.37 & 0.013 & 0.54 \\
\hline \multicolumn{10}{|l|}{ Probability } \\
\hline $\mathrm{Ca}-\mathrm{P}$ & & 0.0014 & 0.0001 & 0.2068 & 0.1527 & 0.0336 & 0.0813 & 0.9640 & 0.0874 \\
\hline Boron & & 0.0070 & 0.2560 & 0.0030 & 0.0808 & 0.5979 & 0.1077 & 0.0016 & 0.3314 \\
\hline Ca-P×boron & & 0.0991 & 0.0047 & 0.6540 & 0.2578 & 0.1376 & 0.0010 & 0.1012 & 0.6531 \\
\hline \multicolumn{10}{|l|}{$\mathrm{Ca}-\mathrm{P}$} \\
\hline Standard & & $728^{\mathrm{a}}$ & $1,084^{\mathrm{a}}$ & 1.585 & 0.555 & $2,263^{\mathrm{a}}$ & 4,246 & 1.913 & 0.88 \\
\hline Deficient & & $714^{\mathrm{b}}$ & $1,050^{\mathrm{b}}$ & 1.565 & 1.222 & $2,231^{\mathrm{b}}$ & 4,187 & 1.913 & 1.66 \\
\hline \multicolumn{10}{|l|}{ Boron } \\
\hline 0 & & $713^{\mathrm{b}}$ & 1,078 & $1.610^{\mathrm{a}}$ & 1.33 & 2,237 & 4,264 & $1.944^{\mathrm{a}}$ & 1.66 \\
\hline 30 & & $729^{a}$ & 1,061 & $1.548^{\mathrm{b}}$ & 1.16 & 2,254 & 4,179 & $1.890^{\mathrm{b}}$ & 1.33 \\
\hline 60 & & $721^{\mathrm{ab}}$ & 1,062 & $1.567^{\mathrm{b}}$ & 0.16 & 2,250 & 4,206 & $1.905^{\mathrm{b}}$ & 0.83 \\
\hline
\end{tabular}

${ }^{\mathrm{a}-\mathrm{d}}$ Means within a column, within main effects, lacking a common superscript differ $(\mathrm{p}<0.05)$.

having their diet enriched with boron $(\mathrm{p}>0.05)$ (Table 4$)$. However, the supplementation diet with $30 \mathrm{ppm}$ boron

Table 4. Serum characteristics of broilers received diets differing in $\mathrm{Ca}$ and $\mathrm{P}$ with or without boron

\begin{tabular}{lccccc}
\hline Ca-P $(\%)$ & $\begin{array}{c}\text { Boron } \\
(\mathrm{ppm})\end{array}$ & $\begin{array}{c}\mathrm{Ca} \\
(\mathrm{mg} / \mathrm{dl})\end{array}$ & $\begin{array}{c}\mathrm{P} \\
(\mathrm{mg} / \mathrm{dl})\end{array}$ & $\begin{array}{c}\text { ALP } \\
(\mathrm{U} / \mathrm{L})\end{array}$ & $\begin{array}{c}\text { ALT } \\
(\mathrm{U} / \mathrm{L})\end{array}$ \\
\hline Standard & 0 & 12.72 & $6.25^{\mathrm{abc}}$ & 690 & 6.58 \\
Standard & 30 & 13.68 & $6.70^{\mathrm{a}}$ & 668 & 6.41 \\
Standard & 60 & 13.74 & $6.34^{\mathrm{ab}}$ & 663 & 6.75 \\
Deficient & 0 & 12.36 & $5.85^{\mathrm{c}}$ & 751 & 6.66 \\
Deficient & 30 & 12.84 & $6.41^{\mathrm{ab}}$ & 646 & 7.00 \\
Deficient & 60 & 12.66 & $6.10^{\mathrm{bc}}$ & 716 & 6.66 \\
SEM & & 0.48 & 0.16 & 90.67 & 0.27 \\
Probability & & & & & \\
Ca-P & & 0.0628 & 0.0801 & 0.3184 & 0.3955 \\
Boron & & 0.2807 & 0.0029 & 0.2865 & 0.4851 \\
Ca-P×boron & 0.7597 & 0.2455 & 0.2555 & 0.9009 \\
Ca-P & & & & & \\
Standard & & 13.38 & 6.43 & 673 & 6.77 \\
$\quad$ Deficient & & 12.60 & 6.12 & 704 & 6.58 \\
Boron & & & & & \\
0 & 12.54 & $6.05^{\mathrm{b}}$ & 720 & 6.50 \\
30 & 13.26 & $6.56^{\mathrm{a}}$ & 657 & 6.70 \\
60 & 12.24 & $6.22^{\mathrm{b}}$ & 689 & 6.83 \\
\hline
\end{tabular}

a-c Means within a column, within main effects, lacking a common superscript differ $(\mathrm{p}<0.05)$. increased the serum $\mathrm{P}$ level compared with the 0 ppm group, whereas no significant increase was the case in the $60 \mathrm{ppm}$ supplemental dose level. The inadequacy of $\mathrm{P}$ in starter and grower diets at about $20 \%$ and $25 \%$, respectively, caused a slight decrease in the serum $\mathrm{P}$ level $(\mathrm{p}=0.08)$.

Table 5 presents ash with $\mathrm{Ca}$ and $\mathrm{P}$ levels determined in tibia and faeces. Neither insufficiency in $\mathrm{Ca}$ and $\mathrm{P}$ nor the fortification diet with boron affected bone breaking strength (p>0.05) (Table 5). Boron at $30 \mathrm{ppm}$ increased tibia ash, $\mathrm{Ca}$ and $\mathrm{P}$ in both standard and Ca-P deficient diets, whereas 60 ppm boron provided no increase in bone $\mathrm{Ca}$ and $\mathrm{P}$, signifying a significant boron by Ca-P interaction $(\mathrm{p}<0.01)$.

No significant boron by Ca-P interaction was found for the indices studied in faeces. Birds fed Ca-P deficient diets had faeces with lower ash, $\mathrm{Ca}$ and $\mathrm{P}$ than those birds that received standard diets $(\mathrm{p}<0.05)$. The supplementation diet with either $30 \mathrm{ppm}$ or $60 \mathrm{ppm}$ of boron resulted in significant reductions in corresponding fecal measurements as compared to no boron addition. However, fecal excretion of ash and p was higher in the 60 ppm group than in the 30 ppm group.

\section{DISCUSSION}

Previous scientific articles have reported conflicting results that differed considerably in their experimental protocols. Diets supplemented with boron have been 
Table 5. Bone breaking strength and mineral characteristics of tibia and faeces of broilers given diets supplemented with or without boron

\begin{tabular}{|c|c|c|c|c|c|c|c|c|}
\hline \multirow{2}{*}{$\mathrm{Ca}-\mathrm{P}(\%)$} & \multirow{2}{*}{$\begin{array}{l}\text { Boron } \\
(\mathrm{ppm})\end{array}$} & \multirow{2}{*}{$\begin{array}{c}\text { Bone breaking } \\
\text { strength } \\
\left(\mathrm{N} / \mathrm{cm}^{2}\right)\end{array}$} & \multicolumn{3}{|c|}{ Tibia (\%) } & \multicolumn{3}{|c|}{ Faeces $(\%)$} \\
\hline & & & Ash & $\mathrm{Ca}$ & $P$ & Ash & $\mathrm{Ca}$ & $\mathrm{P}$ \\
\hline Standard & 0 & 71.07 & $33.18^{\mathrm{c}}$ & $11.23^{\mathrm{bc}}$ & $5.71^{\mathrm{b}}$ & $14.52^{\mathrm{a}}$ & $4.65^{\mathrm{a}}$ & $3.19^{\mathrm{a}}$ \\
\hline Standard & 30 & 69.10 & $35.50^{\mathrm{a}}$ & $11.73^{\mathrm{a}}$ & $6.06^{\mathrm{a}}$ & $13.60^{\mathrm{d}}$ & $3.70^{\mathrm{bc}}$ & $2.19^{b c}$ \\
\hline Standard & 60 & 67.27 & $32.95^{\mathrm{d}}$ & $10.86^{\mathrm{c}}$ & $5.51^{\mathrm{c}}$ & $14.02^{\mathrm{b}}$ & $3.77^{\mathrm{b}}$ & $2.60^{\mathrm{ab}}$ \\
\hline Deficient & 0 & 69.28 & $32.80^{\mathrm{cd}}$ & $11.20^{\mathrm{bc}}$ & $5.52^{\mathrm{c}}$ & $13.89^{c}$ & $4.07^{\mathrm{ab}}$ & $2.56^{\mathrm{ab}}$ \\
\hline Deficient & 30 & 69.22 & $34.27^{\mathrm{b}}$ & $11.32^{\mathrm{ab}}$ & $5.76^{\mathrm{b}}$ & $12.46^{\mathrm{f}}$ & $2.85^{\mathrm{c}}$ & $1.61^{\mathrm{c}}$ \\
\hline Deficient & 60 & 69.09 & $34.07^{\mathrm{b}}$ & $11.15^{\mathrm{bc}}$ & $5.47^{\mathrm{c}}$ & $13.19^{\mathrm{e}}$ & $3.57^{\mathrm{bc}}$ & $2.13^{b c}$ \\
\hline SEM & & 3.69 & 0.14 & 0.14 & 0.06 & 0.06 & 0.28 & 0.23 \\
\hline \multicolumn{9}{|l|}{ Probability } \\
\hline $\mathrm{Ca}-\mathrm{P}$ & & 0.9361 & 0.9815 & 0.6660 & 0.0168 & 0.0001 & 0.0333 & 0.0357 \\
\hline Boron & & 0.6735 & 0.0001 & 0.0115 & 0.0001 & 0.0001 & 0.0057 & 0.0028 \\
\hline $\mathrm{Ca}-\mathrm{P} \times$ boron & & 0.5240 & 0.0001 & 0.0209 & 0.0119 & 0.4110 & 0.3977 & 0.0759 \\
\hline \multicolumn{9}{|l|}{$\mathrm{Ca}-\mathrm{P}$} \\
\hline Standard & & 69.14 & 33.88 & 11.27 & $5.76^{\mathrm{a}}$ & $14.04^{\mathrm{a}}$ & $4.04^{\mathrm{a}}$ & $2.66^{\mathrm{a}}$ \\
\hline Deficient & & 69.19 & 33.71 & 11.22 & $5.58^{\mathrm{b}}$ & $13.18^{\mathrm{b}}$ & $3.49^{\mathrm{b}}$ & $2.10^{\mathrm{b}}$ \\
\hline \multicolumn{9}{|l|}{ Boron level } \\
\hline 0 & & 70.17 & $32.99^{\mathrm{b}}$ & $11.21^{\mathrm{b}}$ & $5.61^{\mathrm{b}}$ & $14.20^{\mathrm{a}}$ & $4.36^{\mathrm{a}}$ & $2.87^{\mathrm{a}}$ \\
\hline 30 & & 69.11 & $34.88^{\mathrm{a}}$ & $11.52^{\mathrm{a}}$ & $5.91^{\mathrm{a}}$ & $13.03^{c}$ & $3.27^{\mathrm{b}}$ & $1.90^{\mathrm{b}}$ \\
\hline 60 & & 68.18 & $33.51^{b}$ & $11.00^{\mathrm{b}}$ & $5.49^{\mathrm{b}}$ & $13.60^{\mathrm{b}}$ & $3.67^{\mathrm{b}}$ & $2.36^{\mathrm{ab}}$ \\
\hline
\end{tabular}

${ }_{\mathrm{a}-\mathrm{f}}$ Means within a column, within main effects, lacking a common superscript differ $(\mathrm{p}<0.05)$.

reported by several researchers to provide satisfactory performance for broilers. Rossi et al. (1993) reported that the dietary supplementation of a basal diet with 5 and 40 $\mathrm{mg} / \mathrm{kg}$ boron improved the growth of male broiler chicks in one experiment. Similarly, Fassani et al. (2004) indicated that supplying boron at 30,60,90 and $120 \mathrm{ppm}$ provided linear increases in body weight at days 21 and 42. In consistent with our findings, some other researchers (Eliot and Edwards, 1992; Kurtoğlu et al., 2001) could not determine a growth promotion effect even with fortified dietary boron up to $300 \mathrm{ppm}$.

The significant decline in feed intake of birds, with respect to 30 and $60 \mathrm{ppm}$ boron supplementation in Ca-P deficient diets, is highly noticeable, despite the fact that, no retardation in body weight and increase in mortality were observed over the whole growth period in such circumstances. In agreement with our findings, Fassani et al. (2004) reported that birds fed with a diet of $30 \mathrm{ppm}$ boron consumed $140 \mathrm{~g}$ less feed than the $0 \mathrm{ppm}$ group while exhibiting better feed conversion and similar mortality rates. However, the specific depressive effect regarding dietary boron supplementation on the feed intake of broilers was barely occasioned with the dietary levels of $300 \mathrm{ppm}$ or more (Rossi et al., 1993).

Based on the feed conversion ratio, a supplemental level of 30 or $60 \mathrm{ppm}$ boron was indicated as promising in both dietary Ca-P levels. We concluded that the results obtained herein concerning feed conversion could be definitive of boron requirements in broiler diets based on maize and soybean meal. This is because promising results were obtained in terms of the feed conversion ratio when modern broiler hybrids were fed on diets supplemented with boron ranging from 25 to 90 ppm (Kurtoğlu et al., 2001; Fassani et al., 2004). However, the biological responses involved in the efficiency of the feed conversion ratio in terms of dietary boron could not be explained by those authors or by us.

Mortality was unaffected by dietary treatments and was generally low; a rate of about 1-2\% implied an excellent general health status for the flock in this study. No scientific evidence has yet been declared showing that dietary boron supplementation was responsible for bird mortality through experimental works in poultry nutrition. The mortality of birds was not significantly different from those of the control until the diets were supplemented with boron by up to 300 ppm (Eliot and Edwards, 1992; Rossi et al., 1993; Wilson and Ruzsler, 1996; Fassani et al., 2004).

The combined evidence up to today has pointed out that boron could interact with the metabolism of some macro minerals such as $\mathrm{Ca}, \mathrm{P}$ and $\mathrm{Mg}$, and ALP, thereby modifying their concentrations in the serum of broiler chickens (Hunt, 1989; Hunt et al., 1994; Kurtoğlu et al., 2001, 2005) and laying hens (Eren et al., 2004). This was the case for the increased serum $\mathrm{P}$ level in our study, but not for the serum 
Ca level and ALP activity. Some results consistent with our findings have been collected previously from broilers with insignificant serum $\mathrm{Ca}$ levels in response to being fed on boron added diets (Eliot and Edwards, 1992; Kurtoğlu et al., 2001). As such, our findings agree with previous reports showing higher levels of plasma phosphorus in broiler chickens (Kurtoğlu et al., 2001) and laying hens (Kurtoğlu et al., 2002; Eren et al., 2004). Increased apparent absorption and balance of $\mathrm{Ca}$ and $\mathrm{P}$ in rats (Hegsted et al., 1991) were correlated to increased serum $\mathrm{Ca}$ and $\mathrm{P}$ levels with retention in bones concerning boron in this work.

Serum ALT activity, as one of the indicators of hepatic boron toxicity, was not affected $(p>0.05)$ by dietary boron supplementation in the present study. Clinical depression signs concerning boron toxication were barely observed at the $400 \mathrm{mg} / \mathrm{kg}$ inclusion level as body weight loss in laying hens (Wilson and Ruszler, 1998). The dietary boron intake in our work (30 and $60 \mathrm{mg} / \mathrm{kg}$ diet) was much lower than in those earlier establishments. Excellent growth performance and mortality rates of broiler chickens in our study as recommended by the breeder also drew attention to a lack of signs of boron toxicity under the experimental conditions of the present study.

In contrast to our findings, research in poultry (Rossi et al., 1993; Wilson and Ruszler, 1998), rats (Chapin et al., 1997) and borrows (Armstrong and Spears, 2001) demonstrated that boron could increase the mechanical properties of bone. As a rule of thumb, bone breaking strength and bone ash are often used as criteria for assessing the value of various dietary supplements (Wilson and Ruszler, 1997, 1998), such as Vitamin $\mathrm{D}_{3}$ and macro elements Ca, P and Mg (Wilson and Ruszler, 1998; Armstrong and Spears, 2001). Considering the proven benefits in bone ash, $\mathrm{Ca}$ and $\mathrm{P}$ measurements in boron-fed birds, we expected an improvement in bone breaking strength in birds given $30 \mathrm{ppm}$ boron, in particular. Due to the very limited reports pertaining to the physiological roles of boron as a microelement in bone mineralization and related effects on bone mechanical properties in fast growing broiler strains (Kurtoğlu et al., 2005), we could not compare our findings to previous results.

Ash with mineral concentrations of tibia and faeces were found in a closely related manner in the present work. Birds receiving a diet with $30 \mathrm{ppm}$ boron retained more $\mathrm{Ca}$, $\mathrm{P}$, and eventually the ash in tibia bones, while excreting less through faeces. It is well known that $\mathrm{Ca}$ and $\mathrm{P}$ are essential elements for normal skeletal growth and bone development. Also, boron seems to have a regulatory role in mineral metabolism, interacting with some macro and micro elements, but the mechanism has not yet been clearly established (Nielsen et al., 1987; Chapin et al., 1988; Brown et al., 1989; Hegsted et al., 1991). The particular mechanism through which boron influences bone development is described as enhancing the macro mineral content of normal bone and some indices of growth cartilage maturation (Hunt et al., 1994). Since the augmentation of boron was not measured in bones or any other tissue in this study, the increased $\mathrm{Ca}$ and $\mathrm{P}$ level in bones was assumed as an indicative for the regulatory role of supplemental boron on bone mineralization. Our results agree with those of Armstrong et al. (2000) and Kurtoğlu et al. (2005) who reported significant increases in the tibia $\mathrm{Ca}$ concentration of broilers in response to dietary boron supplementation, while dissimilar from others reporting no benefits in bone ash and Ca (Rossi et al., 1993; Fassani et al., 2001).

In fact, prior studies regarding dietary boron focused on urinary variables rather than faeces in animal subjects, except for poultry species (Green and Weeth, 1977; Brown et al., 1989; Hegsted et al., 1991; Armstrong and Spears, 2001). Since the most research has been dedicated to zootechnical performance, serum and bone characteristics, little attention has been given to the relationship between dietary boron intake and fecal mineral excretion through experimental studies in poultry species (Qin and Klandorf, 1991; Wilson and Ruszler, 1998; Yeşilbağ and Eren, 2008). Limited scientific evidence appears to confirm our findings that dietary boron supplementation decreased urinary $\mathrm{Ca}$ and $\mathrm{P}$ excretion in rats (Hegsted et al., 1991), P excretion in heifers (Green and Weeth, 1977) and Ca excretion in sheep (Brown et al., 1989).

\section{CONCLUSIONS}

Altogether, boron turned out to be most effective at a dosage of $30 \mathrm{ppm}$ in terms of efficiency of food conversion, in accordance with augmented tibia $\mathrm{Ca}$ and $\mathrm{P}$ reserves and less fecal excretion. One-fold increase in supplemental boron dose provided no more benefits in terms of parameters measured. The outstanding overall performance of birds fed on a diet deficient in $\mathrm{Ca}$ and $\mathrm{P}$ is conclusive.

\section{REFERENCES}

Anonymous. 1991. Animal feed-determination of metabolizable energy (chemical method). Turkish Standards Institute (TSE), Publ. No. 9610:1-32.

AOAC. 1990. Official methods of analysis (15th ed.), Association of official analytical chemists, Washington, DC.

Armstrong, T. A. and J. W. Spears. 2001. Effect of dietary boron on growth performance, calcium, and phosphorus metabolism, and bone mechanical properties in growing barrows. J. Anim. Sci. 79:3120-3127.

Brown, T. F., M. E. Mccormick, D. R. Morris, L. K. Zeringue. 1989. Effects of dietary boron on mineral balance in sheep. Nutr. Res. 9:503-512.

Chapin, R. E., W. W. Ku, M. A. Kenney, H. Mccoy, B. Gladen, R. N. Wine, R. Wilson and M. R. Elwell. 1997. The effects of 
dietary boron on bone strength in rats. Fundam. Appl. Toxicol. 35:205-215.

Eren, M., F. Uyanik and S. Küçükersan. 2004. The influence of dietary boron supplementation on egg quality and serum calcium, inorganic phosphorus, magnesium levels and alkaline phosphate activity in laying hens. Res. Vet. Sci. 76:203-210.

Eliot, M. A. and H. M. Jr. Edwards. 1992. Studies to determine whether an interaction exists among boron, calcium, and cholecalciferol on the skeletal development of broiler chickens. Poult. Sci. 71(4):677-690.

Fassani, E. J., A. G. Bertechini, J. A. G. Brito, R. K. Kato, E. T. Fialho and A. Geraldo. 2004. Boron supplementation in broiler diets. Braz. J. Poult. Sci. 4:213-217.

Gren, G. H. and H. J. Weeth. 1997. Response of heifers ingesting boron in water. J. Anim. Sci. 46:812-818.

Hegsted, M., M. J. Kenan, F. Siver and P. Wozniak. 1991. Effect of boron on vitamin $\mathrm{D}$ deficient rats. Biol. Trace Elem. Res. 28:243-255.

Hunt, C. D. 1989. Dietary boron modified the effects of magnesium and molybdenum on mineral metabolism in the cholecalciferol deficient chick. Biol. Trace Elem. Res. 22:201220.

Hunt, C. D. and F. H. Nielsen. 1981. Interaction between boron and cholecalciferol in the chick. In: Trace element metabolism in man and animals (Ed. J. C. Howell, J. M. Gawthorne and C. L. White). Australian Academy of Science, Canberra, Australia. pp. 597-600.

Hunt, C. D., I. L. Herbel and I. P. Idso. 1994. Dietary boron modifies the effects of vitamin $\mathrm{D}_{3}$ nutriture on indices of energy substrate utilization and mineral metabolism in the chick. J. Bone Miner. Res. 9:171-181.

IPCS. 1998: Environmental health criteria 204. Boron. World Health Organization, Geneva, Switzerland.

Kurtoğlu, V., F. Kurtoğlu and B. Coşkun. 2001. Effects of boron supplementation of adequate and inadequate vitamin $\mathrm{D}_{3^{-}}$ containing diet on performance and serum biochemical characters of broiler chickens. Res. Vet. Sci. 71:183-187.

Kurtoğlu, V., F. Kurtoğlu, B. Coşkun, E. Şeker, T. Balevi and I. S. Çetingül. 2002. Effects of boron supplementation on performance and some serum biochemical parameters in laying hens. Rev. Med. Vet. 153(12):823-828.
Kurtoğlu, F., V. Kurtoğlu, İ. Çelik, T. Keçeci and M. Nizamlıŏlu. 2005. Effects of dietary boron supplementation on some biochemical parameters, peripheral blood lymphocytes, splenic plasma cells and bone characteristics of broiler chicks given diets with adequate or inadequate cholecalciferol (vitamin $\mathrm{D}_{3}$ ) content, Br. Poult. Sci. 46(1):87-96.

Naumann, C. and R. Bassler. 1993. Chemical analyses of feedstuff Method book III. (Ed). VDLUFA- Press. Darmstadt, Germany.

Nielsen, F. H. 1992. Fact and fallacies about boron. Nutrition Today, May/June, pp. 6-12.

Nielsen, F. H. and T. R. Shuler. 1992. Studies of the interaction between boron and calcium, and its modification by magnesium and potassium, in rats. Effects on growth, blood variables and bone mineral composition. Biol. Trace Elem. Res. 35:225-237.

Nielsen, F. H., C. D. Hunt, L. Mullen and J. R. Hunt. 1987. Effect of dietary boron on mineral, estrogen, and testosterone metabolism in postmenopausal women. FASEB J 1:394-397.

NRC (National Research Council). 1994. Nutrients requirements of poultry. 9th Ed. Washington, DC: National Academic Pres; p. 155.

Qin, X. and H. Klandorf. 1991. Effect of dietary boron supplementation on egg production, shell quality, and calcium metabolism in aged broiler breeder hens. Poult. Sci. 70(10): 2131-2138.

Rossi, A. F., R. D. Miles, B. I. Damron and L. K. Flunker. 1993. Effects of dietary boron supplementation on broilers, Poult. Sci. 72(11):2124-2130.

SAS Institute, SAS User's Guide, Statistics Edition. 1995. SAS Institue Inc. NC. USA.

Wilson, J. H. and P. L. Ruszler. 1996. Effects of dietary boron supplementation on laying hens, Br. Poult. Sci. 37:723-729.

Wilson, J. H. and P. L. Ruszler. 1997. Effects of boron on growing pullets. Biol. Trace Elem. Res. 56(3):287-294.

Wilson, J. H. and P. L. Ruszler. 1998. Long term effect of boron layer bone strength and production parameters, Br. Poult. Sci. 39:11-15.

Yeşilbağ, D. and M. Eren. 2008. Effects of dietary boric acid supplementation on performance, eggshell quality and some serum parameters in aged laying hens. Turky J. Vet. Anim. Sci. 32(2):113-117. 